BY JEAN-PAUL FOUCHER, GRAHAM K. WESTBROOK, ANTJE BOETIUS, SILVIA CERAMICOLA, STÉPHANIE DUPRÉ,

JEAN MASCLE, JÜRGEN MIENERT, OLAF PFANNKUCHE,

CATHERINE PIERRE, AND DANIEL PRAEG

\title{
Structure and Drivers of
}

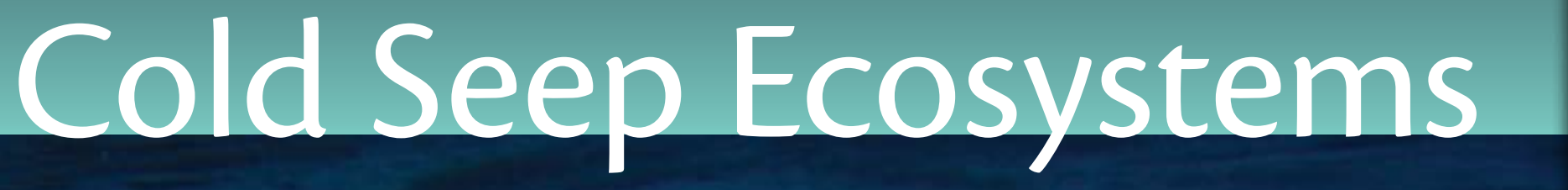

A gyre in the brine pool that occupies the crater of Cheops mud volcano, Nile-Deep Sea Fan, at $3-\mathrm{km}$ water depth. The gyre is about 2-m across, and shows sulfur-rich white "foam" accumulations, thought to be produced by bacterial activity. This image was taken by ROV Victor during Ifremer's MEDECO cruise in 2007. 
ABSTRACT. Submarine hydrocarbon seeps are geologically driven "hotspots" of increased biological activity on the seabed. As part of the HERMES project, several sites of natural hydrocarbon seepage in the European seas were investigated in detail, including mud volcanoes and pockmarks, in study areas extending from the Nordic margin, to the Gulf of Cádiz, to the Mediterranean and Black seas. High-resolution seabed maps and the main properties of key seep sites are presented here. Individual seeps show ecosystem zonation related to the strength of the methane flux and distinct biogeochemical processes in surface sediments. A feature common to many seeps is the formation of authigenic carbonate constructions. These constructions exhibit various morphologies ranging from large pavements and fragmented slabs to chimneys and mushroom-shaped mounds, and they form hard substrates colonized by fixed fauna. Gas hydrate dissociation could contribute to sustain seep chemosynthetic communities over several thousand years following large gas-release events.

\section{INTRODUCTION}

Since the first discovery of a hydrocarbon-associated cold seep community off Louisiana (Kennicut et al., 1985), hydrocarbon seepage and its close association with "hotspots" of increased biological activity have been documented at a number of seafloor sites worldwide (Judd and Hovland, 2007). Geological structures associated with the expulsion of hydrocarbon-rich fluids, such as mud volcanoes and pockmarks, have been recognized on the margins of the Atlantic Ocean, the Mediterranean Sea, and the Black Sea, and new seepage sites continue to be discovered. HERMES project scientists mapped, observed, and sampled key seep sites along the Nordic margin, in the Gulf of Cádiz, and in the eastern Mediterranean and Black seas (Figure 1). Considerable progress has been made in the description and understanding of the biological activity and the processes that drive fluid seepage at these sites. This paper presents information on the structure and driving processes of major seeps investigated in detail during the HERMES project. A companion paper (Vanreusel et al., this issue) describes biological communities at these sites.

\section{MAJOR SEEPS IN \\ EUROPEAN SEAS \\ The Nordic Margin (Figure 1a) \\ The Håkon Mosby Mud Volcano}

The Håkon Mosby mud volcano

(HMMV; Figure 2) is located on the Southwest Barents Sea slope in a water depth of $1270 \mathrm{~m}$. Since its discovery in 1989 (Crane et al., 1995) as a circular, $1-\mathrm{km}$ diameter feature in side-scan sonar images, the HMMV has been the target of numerous research expeditions. The mud and fluid expelled from the volcano may arise from a source depth of 2-3 $\mathrm{km}$ below the seabed within over- pressurized oozes lying below glacial deposits. Milkov et al. (1999) compiled the first map of the HMMV landscape from video and photo surveys. Further fieldwork revealed concentric zones of seafloor morphology, litho-types, and geochemical and biological processes (Milkov et al., 2004; De Beer et al., 2006; Jerosch et al., 2007), and demonstrated exceptionally high activity of mud, fluid, and gas ejections through the surface of the volcano (Sauter et al., 2006).

Geothermal modeling indicates current aqueous flow rates of up to 4-10 $\mathrm{m} \mathrm{y}^{-1}$ at the center of the volcano (Feseker et al., 2008), rapidly decreasing to less than $1 \mathrm{~m} \mathrm{y}^{-1}$ on its perimeter. The expelled fluid is saturated with methane, mainly of biogenic origin, and gas hydrate is abundant in the subsurface (Ginsburg et al., 1999). Detailed observations of the various habitats and the biogeochemical processes involved in each 
of them were made during the HERMES cruises using R/V Pourquoi pas? in 2006 and R/V Polarstern in 2007. High flow rates are restricted to the narrow central area of the feeder channel (about 100-m wide), which shows a gray mud breccia at its surface. In this area, the flow of methane-laden but sulfate-free subsurface fluids is so high that methane oxidation can only occur in the top few millimeters of sediment populated by aerobic methanotrophs (Niemann et al., 2006b). This central area is surrounded by a zone of lower fluid flow and relatively high rates of anaerobic methane oxidation of 4-10 $\mathrm{mmol} \mathrm{m}^{-2} \mathrm{~d}^{-1}$ in the top few centimeters, where sulfate can penetrate from the overlying bottom water. This zone is covered by white mats of giant sulfide-oxidizing filamentous bacteria that profit from the high sulfide flux (De Beer, 2006). Low fluid flow in the outer part of the mud volcano is associated with dense

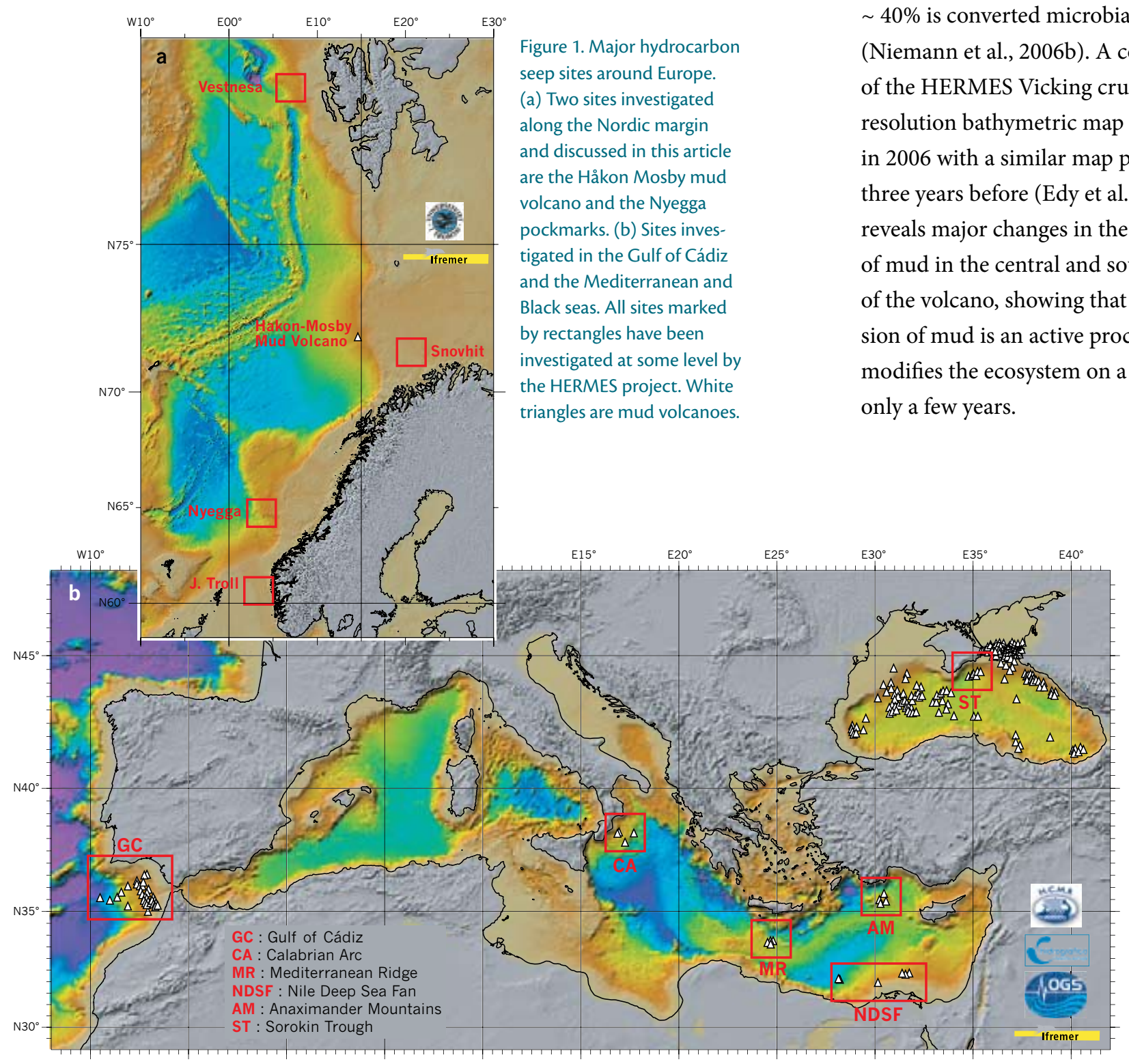




\section{Pockmark Fields on the}

\section{Norwegian Margin Seabed}

The Norwegian continental margin, including the Barents Sea and Northwest Svalbard, contains large pockmark fields on the seafloor connected to subsurface chimney structures. Pockmark fields exist

\section{Jean-Paul Foucher (Jean.Paul.Foucher@} ifremer.fr) is Research Scientist, Géosciences Marines, Centre Ifremer de Brest, Plouzané, France. Graham K. Westbrook is Professor of Geophysics, School of Geography, Earth and Environmental Sciences, University of Birmingham, Birmingham, UK. Antje Boetius is Head, Microbial Habitat Group, Max Planck Institute for Marine Microbiology, and Professor, Jacobs University Bremen, Bremen, Germany.

Silvia Ceramicola is a researcher at the Istituto Nazionale di Oceanografia e di Geofisica Sperimentale (OGS), Sgonico (TS), Italy. Stéphanie Dupré is a researcher at the Laboratoire d'Océanographie et du Climat: Expérimentation et Approches Numériques (LOCEAN), Université Pierre et Marie Curie (UPMC), Paris, France. Jean Mascle is Research Scientist, Géosciences Azur (UMR 6526), Observatoire Océanologique de Villefranche sur Mer, Villefranche-sur-Mer, France.

Jürgen Mienert is Professor, Department of Geology, University of Tromsø, Norway.

\section{Olaf Pfannkuche is Doctor rerum}

naturalium, Leibniz-Institute of Marine Sciences IFM-GEOMAR, Kiel, Germany.

Catherine Pierre is Directeur de recherches au CNRS, Laboratoire d'Océanographie et du Climat: Expérimentation et Approches Numériques (LOCEAN), Université Pierre et Marie Curie (UPMC), Paris, France.

Daniel Praeg is a researcher at the Istituto Nazionale di Oceanografia e di Geofisica Sperimentale (OGS), Sgonico (TS), Italy.
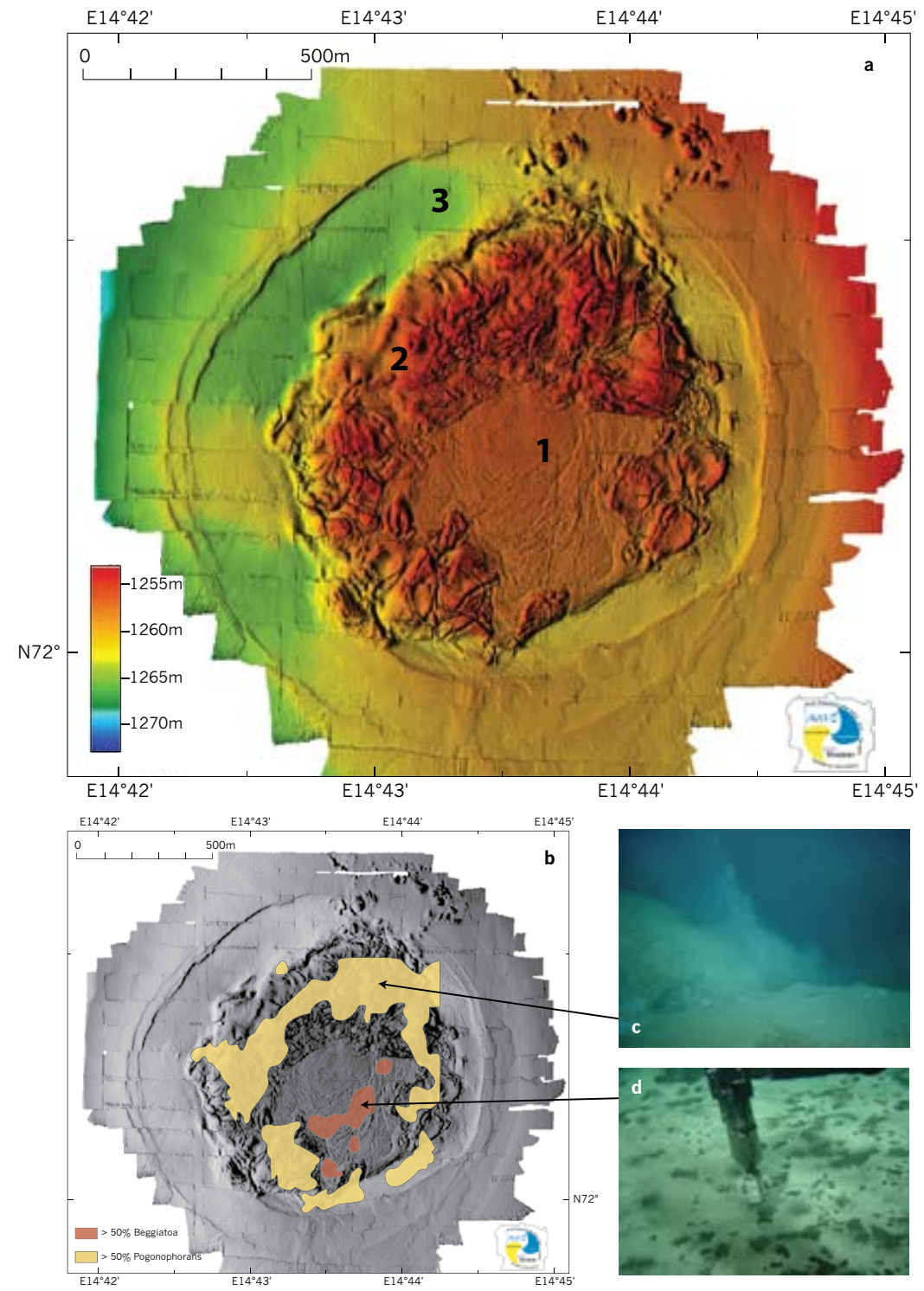

Figure 2. (a) High-resolution bathymetric map of the Håkon Mosby mud volcano showing three main morphological units: (1) a flat central and southern part interpreted as an area of recent mud flows, (2) a hummocky seabed area interpreted as composed of deformed old mud flows, and (3) a pronounced moat at the periphery of the volcano. (b) Colored areas, superimposed on the shaded bathymetry, indicate main areas colonized by pogonophorans and Beggiatoa. After Jerosch et al., 2007. (c) String of free hydrate-coated methane bubbles rising from a seabed fissure that crosses a field of pogonophorans (partially covered by fresh mud) at the surface of the mud volcano. (d) Densely distributed Beggiatoa mats.

in water depths of 50-500 m on the seabed of the Barents Sea in the north, and in the Norwegian trench and the North Sea in the south (Figure 1a) (e.g., Judd and Hovland, 2007). More than a hundred thousand of them, ranging in size from meters to several hundreds of meters wide and a few meters deep, have developed in areas covered by an ice sheet and/or ice streams during the last ice age. During the Pleistocene, the glaciers repeatedly eroded and compacted 


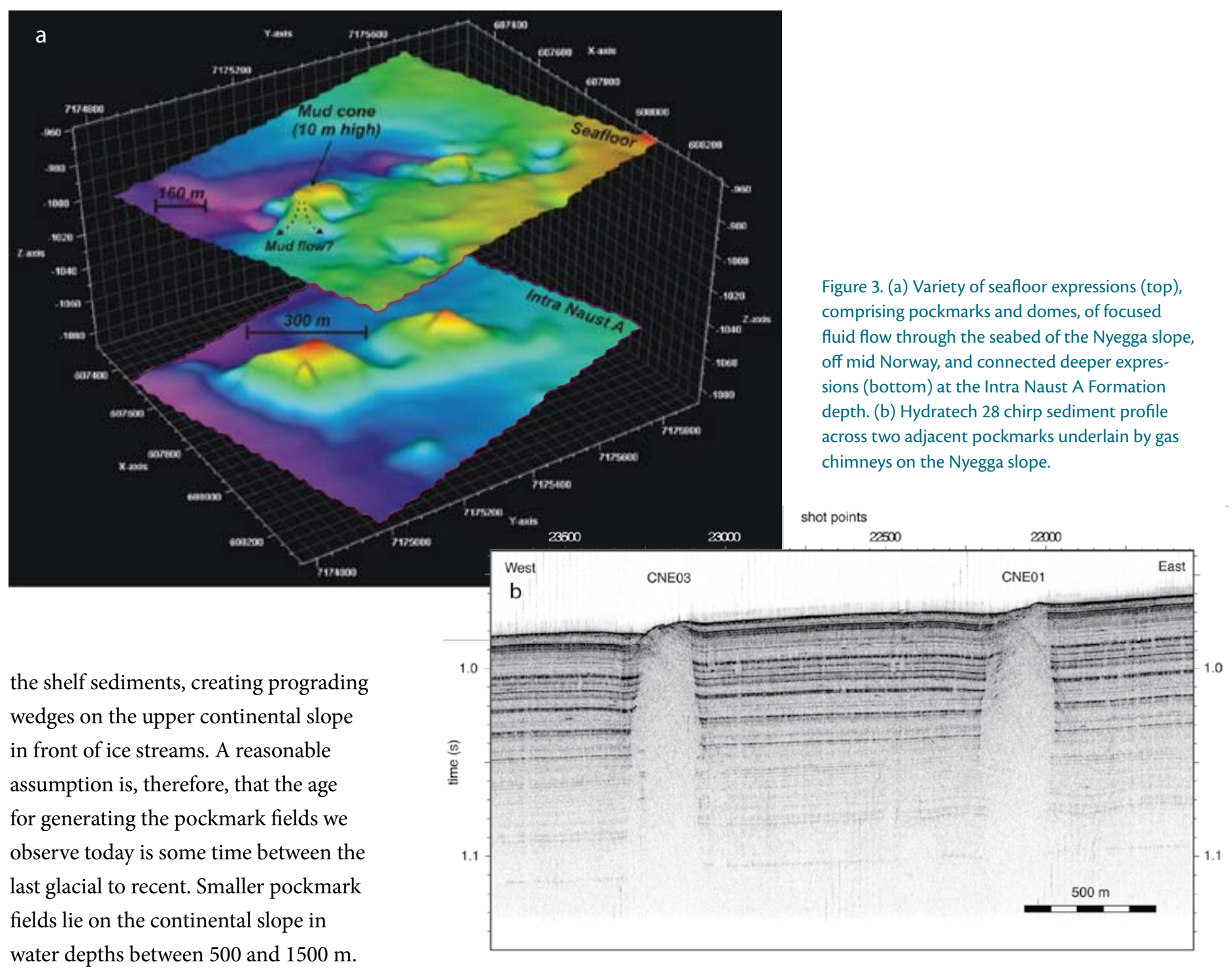

They are occupied by more than several hundreds of seabed depressions up to 20-m deep and several hundred meters wide. The pockmarks were formed by fluids and gases seeping through the seabed, but their formation has not been dated accurately, and the details of the rates of fluid flow and related biological processes within and adjacent to them are still not well understood (Hustoft et al., 2007).

HERMES researchers concentrated their geophysical, geochemical, and biological studies on a smaller pockmark field that lies on the mid-Norwegian margin at Nyegga in 600-800-m water depth (Figures 1a and 3a). Seismic investigations provided evidence at several pockmarks for underlying gas chimneys

(Figure 3b), and detailed examinations of individual pockmarks using remotely operated vehicles (ROVs) provided information on active or recent seeps and biological activity. Initial conclusions were that the chimneys under investigation diffused methane slowly through vast areas of the seafloor where pogonophoran fields were mapped. The most active seeps were found at a few spots, tens of centimeters across, in the central areas. These spots showed a concentric colonization, often characterized by an innermost part composed of black sediments sometimes covered by whitish filaments of giant sulfide-oxidizing bacteria, and an outer, surrounding part colonized by gastropods. Rates of anaerobic methane oxidation in the blackened, sulfidic sediments of the innermost part reach up to $100 \mathrm{mmol} \mathrm{m}^{-2} \mathrm{~d}^{-1}$, which is among the highest rates ever measured at seeps. However, the zones where such high rates occur are limited to a few decimeters, probably representing the central pathways for gas escape. Blocks of methane-derived authigenic carbonates, as previously reported by Mazzini et al. (2006) for the same area and also documented from Norwegian Trench pockmarks (Forsberg et al., 2005), occupy most of the pockmarks 
investigated (Figure 9a), where they form a hard substratum for the development of benthic colonies (Vanreusel et al., this issue). Previous carbon isotope analyses from carbonates retrieved from pockmarks in this area indicate mixed sources of biogenic and thermogenic gases $\left(\delta^{13} \mathrm{C}\right.$ values between $-29.4 \%$ and $-58 \%$ V-PDB, from HERMES results and previously published values from Hovland et al., 2005, and Mazzini et al., 2006). Thermogenic gases are suspected to leak from deep hydrocarbon traps.

\section{The Gulf of Cádiz (Figure 1b)}

Active mud volcanism in the Gulf of Cádiz is a widespread phenomenon, extending from the Iberian-Moroccan shelf to the deeper regions in the center of the Gulf of Cádiz. During HERMES cruise MSM $1 / 3$ in early 2006 , the Captain Arutyunov mud volcano (CAMV) at about 1320-m water depth in the central Gulf of Cádiz (Figure 4) was investigated in great detail by means of in situ biogeochemical and fluid-flux observatories (Sommer et al., 2008, in press). Seafloor observations revealed distinct habitats on top of CAMV that were closely associated with methane seepage and high methane pore water concentrations close to the sediment surface. These habitats comprise seafloor areas densely populated by siboglinid tubeworms (siboglinid habitat) and sediments where siboglinids occurred only sporadically, but numerous unsorted clasts of mainly mudstones were present (clast habitat). On the flanks of the CAMV, seabed morphology changed and no further indications of fluid or gas seepage were found. Seabed methane emission was lowest from the siboglinid habitat (0.001 $\left.\mathrm{mmol} \mathrm{m}^{-2} \mathrm{~d}^{-1}\right)$ compared to the clast habitat $\left(0.27 \pm 0.25 \mathrm{mmol} \mathrm{m}^{-2} \mathrm{~d}^{-1}\right.$, mean \pm SD) (cf. Sommer et al., in press). In the clast habitats, the sulfate-methane reaction zone was located very deep, below the maximum penetration depth for siboglinids, which may cause a partial oxygenation of the upper sediment layers by bioirrigation. The spatial distribution of these habitats, in combination with the in situ seabed methane emission rates, which were assumed to be typical for the respective habitats, was used to calculate a total emission of dissolved methane from CAMV of $0.006 \times 10^{6} \mathrm{~mol} \mathrm{yr}^{-1}$. This

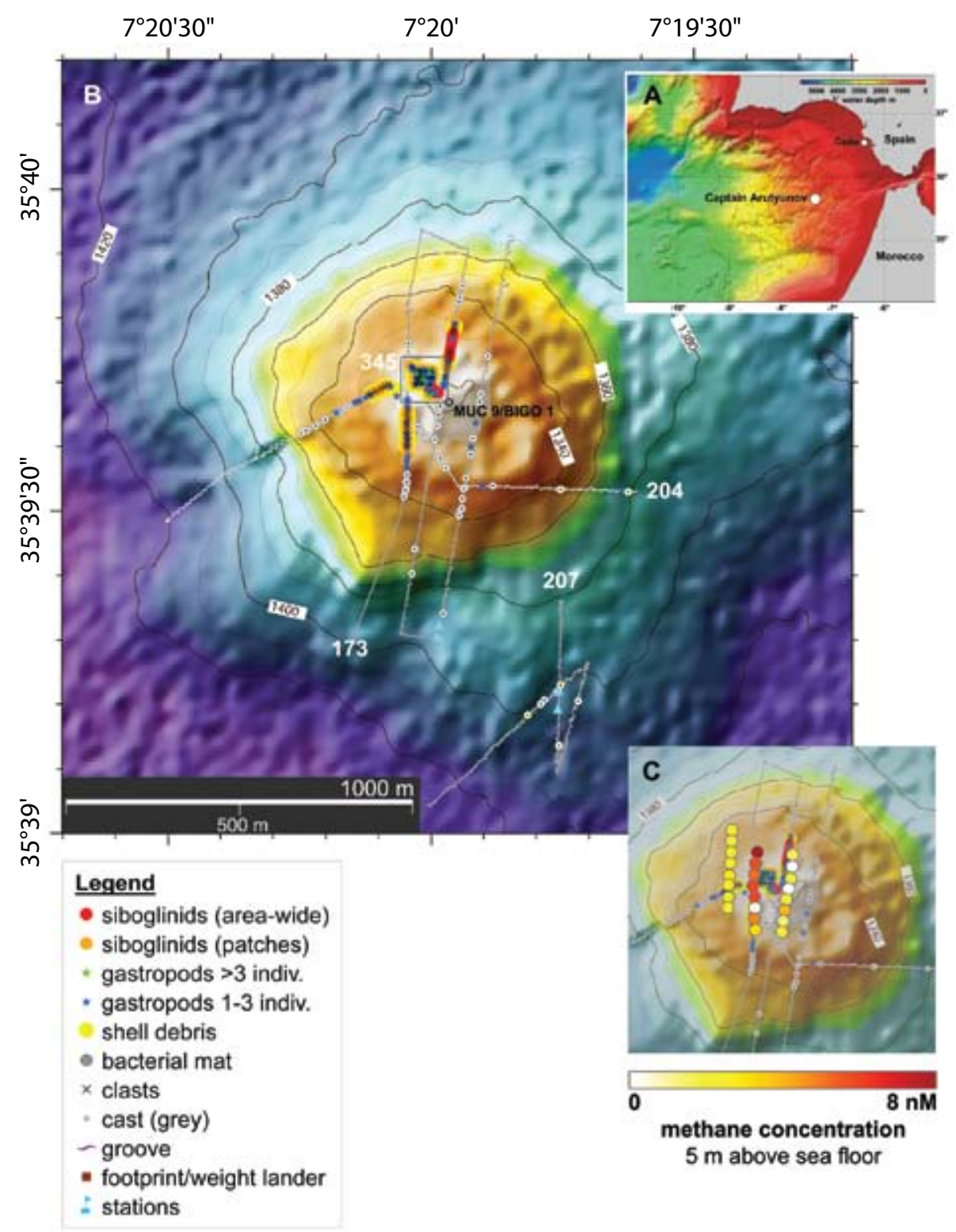

Figure 4. (A) Overview map of the Captain Arutyunov mud volcano in the Gulf of Cádiz. (B) Bathymetric map of the Captain Arutyunov mud volcano displaying distribution patterns of major faunal groups and lithological features. (C) Methane concentration measured $\sim 5 \mathrm{~m}$ above the seafloor indicated by color graded dots overlying the bathymetric map (Sommer et al., in press). 
estimate does not include eruptive events and gas bubbling of methane into the water column. The total seabed methane emission from CAMV is small compared to the overall methane release from other known mud volcanoes (i.e., HMMV). Such low methane emission appears to be related to slow fluid flow, which provides time for anaerobic methanotrophic bacteria (microbial filter) to consume a large proportion of the ascending methane, and for a well-established habitat dominated by siboglinids to settle, which directly and indirectly affects methane turnover. A hydro-acoustic survey of the water column conducted for several days during the MSM 1/3 cruise revealed only weak gaseous methane emissions from CAMV, which correlates with low methane concentrations in the lower water column (Figure 4, cf. Sommer et al., in press). However, strongly elevated methane concentrations in the bottom water of up to $20 \mu \mathrm{M}$ (up to $1 \mathrm{~m}$ above the seafloor) imply that there were localized sites with enhanced, probably periodic, methane release.

\section{The Eastern Mediterranean Sea}

\section{(Figure1b)}

The eastern Mediterranean Sea contains one of the world's highest abundances of mud volcanoes (Kopf, 2002), both along the passive (rifted) margins of northern Africa and the active (subducting) margins of southern Europe. Mud volcanoes were first discovered on the western Mediterranean Ridge accretionary prism (Cita et al., 1981) and in its central area within the well-known Olimpi mud volcano field (Cita and Camerlenghi, 1990; Ivanov et al., 1996; Huguen et al., 2004). Analysis of materials from the latter, retrieved during Ocean Drilling Program
Leg 160, showed that they have been extruding mud, fluids, and gas for at least the last million years, during dewatering of the accretionary prism from depths of up to $7 \mathrm{~km}$ (Robertson et al., 1996). Many more fluid seep-related seabed structures have been identified subsequently, in the Anaximander Mountains (Woodside et al., 1998; Lykousis et al., in press), along the Florence Rise (Woodside et al., 2002; Zitter, 2004), in the Levantine Basin (Coleman and Ballard, 2001), and on the Nile Deep Sea Fan (Bellaiche et al., 2001; Mascle et al., 2001; Loncke et al., 2004). Bathymetry maps and acoustic images of the seafloor obtained using ship-mounted multibeam echosounders (Loubrieu et al., 2001; MediMap Group et al., 2005, 2008) have played key roles in the discovery of fluid-escape structures in the eastern Mediterranean Sea. They have triggered several further investigations at a higher spatial resolution, including those using manned submersibles and ROVs, during which active processes of fluid seepage were investigated (Huguen et al., 2005; Zitter et al., 2005; Dupré et al., 2007).

\section{A feature of the Mediterranean Sea} is the widespread occurrence of thick salt-rich strata deposited during the desiccation event that occurred in the area in Messinian times, during the latest Miocene between 5.3 and $6 \mathrm{Ma}$ (Hsu et al., 1973; Ryan, 1978; Sage and Le Touzey, 1990). This environmental crisis led to the deposition of evaporitic sequences of carbonates, laminated and selenetic gypsum, halite, and potash salts in different morphostructural settings (e.g., shallow basins, deep basins) (Hsu et al., 1973). The total thickness of Messinian strata may reach $2 \mathrm{~km}$ in some of the deep basins, particularly in the eastern Mediterranean Sea, and locally up to $3 \mathrm{~km}$ as a consequence of post-depositional, gravity-driven tectonic deformation along basin margins. The Messinian evaporitic strata were deposited over thick sediments with high organic matter contents that accumulated in relatively confined domains. Progressive "cooking" of this organic matter in response to rapid burial by Messinian and Plio-Quaternary sediments resulted in the generation of hydrocarbon gases and fluid overpressures below the evaporites. Warm fluids dissolve parts of the salt-bearing sediments, thus forming brines. Brine seepage to the seafloor is a result of fluid release along faults piercing the evaporites. The muddy brines are often rich in thermogenic and biogenic hydrocarbon gases produced below the evaporites.

Most HERMES investigations have been conducted in two main areas, the Nile Deep Sea Fan and the Calabrian Arc, in addition to complementary studies on the Mediterranean Ridge and the Anaximander Mountain areas.

\section{The Nile Deep Sea Fan (NDSF)}

Along the Mesozoic rifted continental margin of northern Egypt, sedimentary basins were subject to rapid subsidence and abundant sedimentation, leading to the burial of thick accumulations of organic-rich sediments and the formation of hydrocarbons (Dolson et al., 2001). Deposition of evaporites during the Messinian (Hsu et al., 1973; Ryan, 1978; Sage and Letouzey, 1990) sealed the petroleum system. Hydrocarbons combined with water and mud were later released through faults piercing the Messinian evaporites and forming preferential conduits to the seabed 
(Loncke et al., 2004). Additionally, during the Messinian, the margin was incised by large-scale canyons that were infilled later by Pliocene sediments and have subsequently formed hydrocarbon reservoirs (Aal et al., 2001; Dolson et al., 2002). At present, the Nile Deep Sea Fan is a sedimentary edifice more than 10-km thick (Aal et al., 2001; Mascle et al., 2003; Camera, in press).

The NDSF hosts numerous active fluid/brine escape structures (Loncke et al., 2004; Bayon et al., in press; Huguen et al., in press), including several large gas-emitting mud volcanoes (Dupré et al., 2007). These latter features lie along the present-day continental platform boundary or close to the limit of the Messinian platform.

The Amon mud volcano (Figure 5) illustrates a type of mud volcano formed at the outer limit of the Messinian platform. It is an approximately circular feature, $2.7 \mathrm{~km}$ in diameter, $90 \mathrm{~m}$ in height, with a morphology characterized by numerous concentric ridges and gullies around a central dome. The disturbed summit, about $125 \mathrm{~m}$ in diameter, shows a chaotic layout of mud blocks that suggests a recent or ongoing active deformation, most likely caused by mud extrusion and gas expansion. The warm mud temperature measured up to several tens of degrees to depths of $10 \mathrm{~m}$ below the seabed, and the pore water chemistry indicates active aqueous seepage through the seabed at rates of several meters per year (Feseker et al., in press). This zone of quite limited lateral extent defines the main area of methane seepage.

The Chephren mud volcano illustrates a type of mud volcano formed above the Messinian platform. This mud volcano complex is approximately $1 \mathrm{~km}$ in diameter with an average elevation of $40 \mathrm{~m}$. HERMES investigations during the MEDECO expedition of R/V Pourquoi pas? in 2007 produced the first detailed

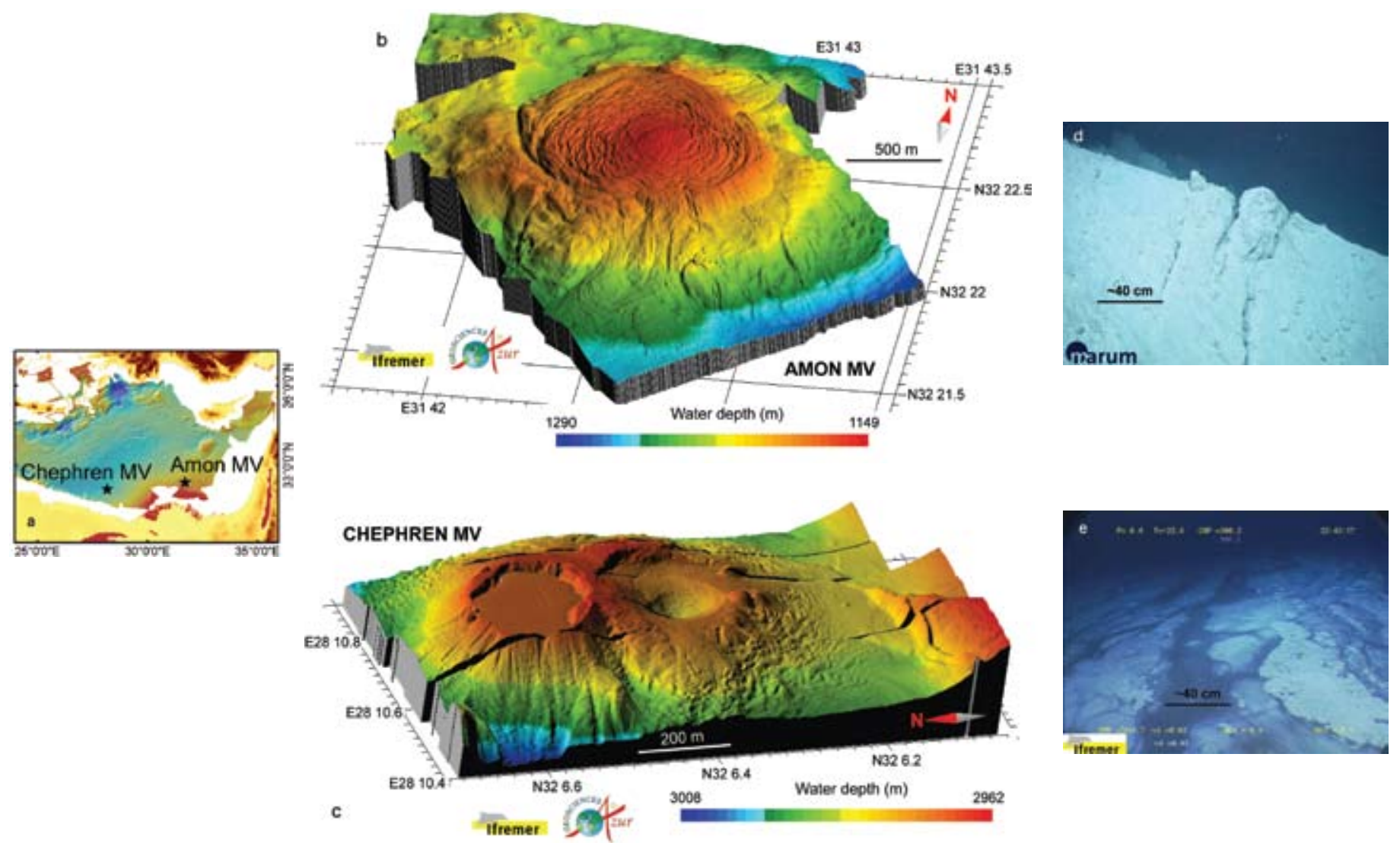

Figure 5. (a) Eastern Mediterranean bathymetric map (MediMap Group et al., 2005) with locations of the Amon and Chephren mud volcanoes. (b) and (c) Detailed shaded three-dimensional bathymetry blocks of Amon and Chephren mud volcanoes, both with a vertical exaggeration of six. The Amon data were acquired by AUV during the BIONIL expedition (2006). The Chephren data were acquired by ROV during the MEDECO Leg 2 expedition (2007). These data were processed using Caraibes (OIfremer) by G. Buffet and L. Brosolo, using 2-m and 1-m pixel grids, respectively. (d) Seafloor photo of the chaotic center of Amon mud volcano (BIONIL 2006). (e) Seafloor photo of the surface of the northern brine lake of Chephren mud volcano (MEDECO, 2007). 
seafloor maps of Chephren mud volcano, revealing a double crater, one filled with a fluid briny mud and the second empty. The temperature of the brine at the northern Chephren lake was measured as high as $57^{\circ} \mathrm{C}$ throughout the brine layer at about 200-m depth. Intense microbiological activity has developed at the surface of Chephren mud volcano.

The central zone of the NDSF is characterized by the occurrence of numerous pockmarks that form subcircular depressions a few meters in diameter and about one meter deep. They are detected by acoustic imagery where the high backscatter corresponds to carbonates that cover large seafloor areas. Reduced sediments and microbial mats surround these structures that host very rich ecosystems of tubeworms, bivalves, urchins, and crustaceans.
A Frontier Area: The Calabrian Arc In contrast to other eastern Mediterranean accretionary prisms, the seabed of the Calabrian Arc had not been investigated for almost 25 years prior to the HERMES project (Stride et al., 1977; Rossi and Sartori, 1981), and mud volcanoes had not been identified, although their presence were suspected (Fusi and Kenyon, 1996; Sartori, 2003). Mud volcanoes were discovered in summer 2005 during the joint HERMES-HYDRAMED campaign of the Italian research vessel OGS Explora (Ceramicola et al., 2006), which obtained the first regional multibeam coverage (Figure 6a). Probable mud volcanoes across the central to inner arc were proven at three sites from gravity cores of mud breccia (Figure 6a) and two of the sites were investigated using two- and three-dimensional seismic reflection methods. These two sites, referred to as the Madonna dello Ionio and the Pythagoras mud volcanoes (Figure 6), were subsequently visited using ROVs during HERMES expeditions aboard R/V Meteor in 2006 and R/V Pourquoi pas? in 2007. Together these investigations have shown that the Calabrian Arc mud volcanoes record a long history of extrusive activity that continues to support "hotspot" seabed ecosystems.

HERMES studies have focused on the Madonna dello Ionio, a complex of three mud volcanoes in water depths of 1600-1800 $\mathrm{m}$ that together resemble a reclining woman (Figure 6b). The "head" of the Madonna is a caldera about 3-km across, surrounded by a halo-like ridge up to 50-m high, while her "breasts" are twin mud cones each up to $140-\mathrm{m}$
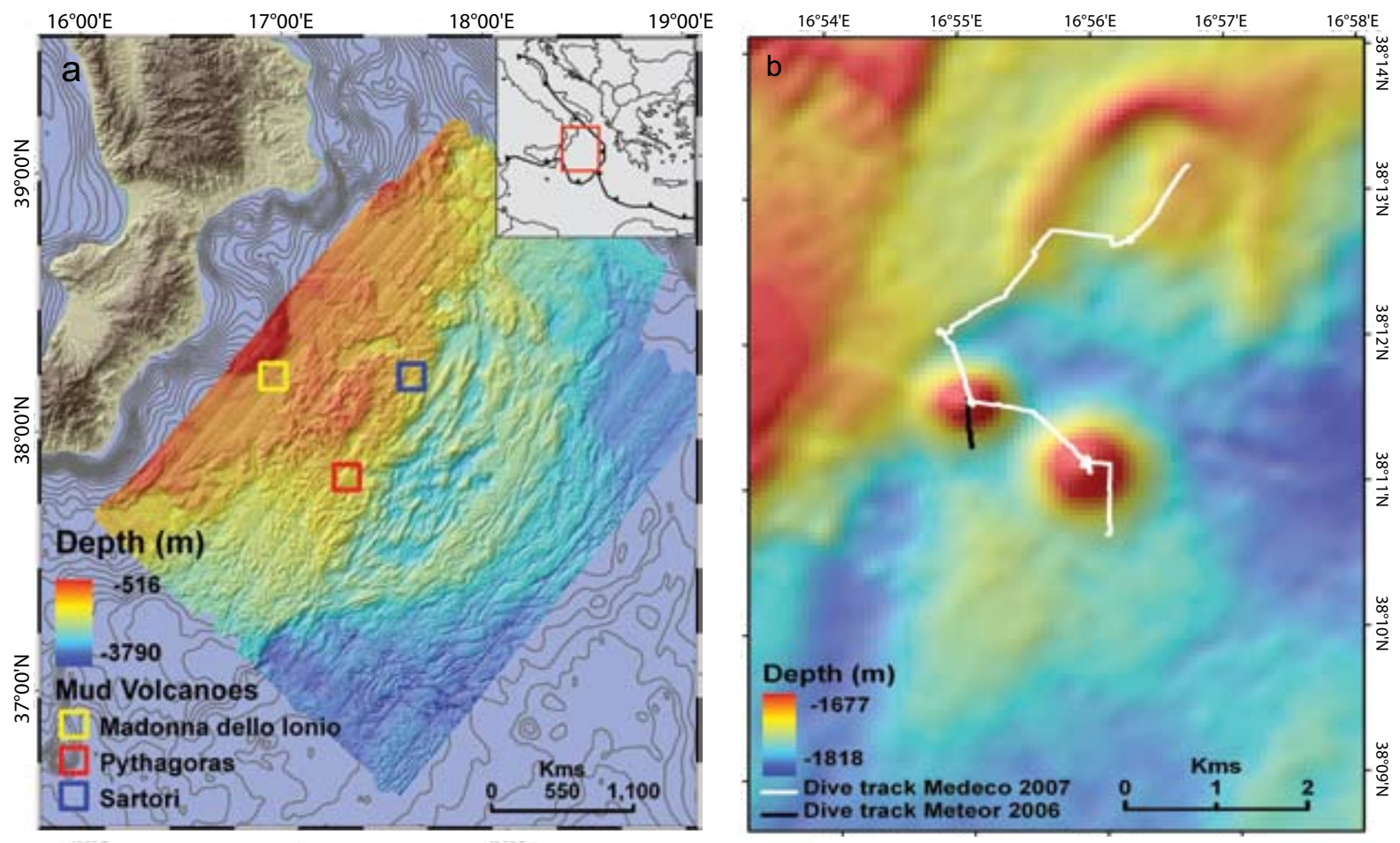

Figure 6. (a) Swath bathymetry of the Calabrian Arc showing locations of mud volcanoes proven by coring. (b) The Madonna dello lonio mud volcanoes. Black and white lines show the tracks of the ROV dives undertaken during HERMES campaigns in 2006 and 2007. 


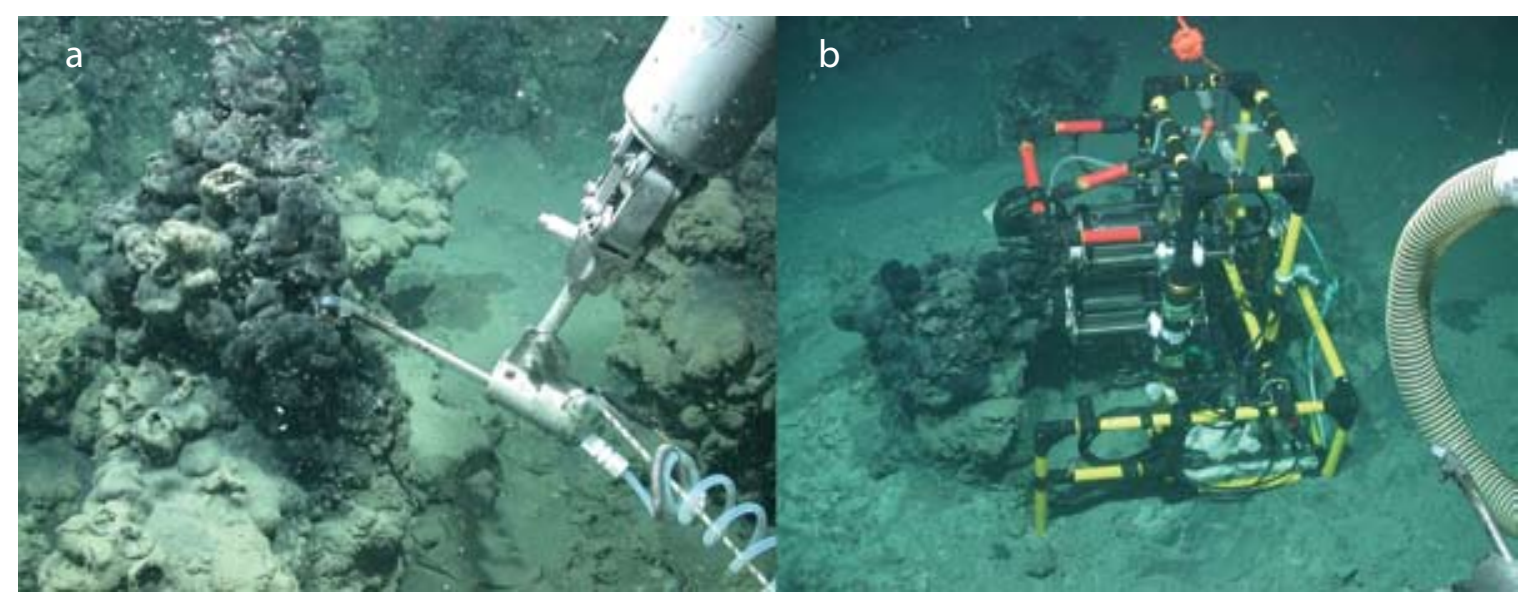

Figure 7. Microbial reefs associated with gas seepage on the Crimean slope. (a) Measurement of gas content of bottom waters around the microbial reefs. (b) Horizontal profiling of sulfide and $\mathrm{pH}$ gradients in the microbial reefs. Source: MARUM/MPI; M72/2

high and $1.5-\mathrm{km}$ wide; her outline is completed by seabed faults northwest of the twin cones that extend for several kilometers to the southwest and are likely to record subsidence due to mud extrusion (Figure 6b). Seismic reflection data across the Madonna show that the seabed mud volcanoes are the tops of extrusive edifices that extend over $1 \mathrm{~km}$ into the subsurface and display interfingering relationships with the flanking Plio-Quaternary succession indicative of episodic extrusive activity over the last several million years.

Seabed samples and ROV investigations of the Madonna dello Ionio mud volcanoes provide evidence of ongoing seepage activity. Gravity cores show grey mud breccias lying at or near the seabed at all three extrusive centers, with gas observed escaping from some cores. ROV investigations (video observations, sampling, and geothermal probes) show that the extrusion of mud breccias has given way to more local extrusion of mud. Fresh outflows of reduced grey mud were observed and sampled at two of the three extrusive centers, and geothermal measurements showed that all three centers were characterized by higher gradients than adjacent areas $\left(>1^{\circ} \mathrm{C} \mathrm{m}^{-1}\right.$ at the Madonna left breast vs. $0.01^{\circ} \mathrm{C} \mathrm{m}^{-1}$ background values). Evidence that this activity supports anoxic ecosystems comes from a $30-\mathrm{cm}$ blade core from the southeast cone, which contained chemolithotrophic tubeworms (polychaetes), indicating reduced conditions at or near the seabed (A. Andersen, CNRS-Roscoff, pers. comm., November 2008). ROV investigations of the summit of the Pythagoras mud volcano also provide evidence of a recent and violent extrusive episode, suggested by an area of chaotic seabed, with irregular relief developed in exposed mud breccias.

\section{The Black Sea}

In the Black Sea, unique microbial habitats of previously unknown biomass accumulations form above gas seeps where oxygen is absent, thus precluding the existence of any higher life forms. The absence of oxygen affects the biogeochemistry of methane and sulfur turnover considerably (Jørgensen et al., 2001), making the Black Sea an interesting natural laboratory for studying anoxic microbial processes. The HERMES "Microhab" expedition with R/V Meteor (M72/2) in early 2007 focused on high-resolution mapping of microbial habitats, detailed in situ geochemical measurements, and sampling for microbial diversity analyses at several seep systems. Selection of study sites was based on previous work by Russian scientists (cf. Ivanov et al., 1996).

In the northwestern Black Sea, hundreds of active gas seeps occur along the shelf edge west of the Crimea peninsula at water depths between 35 and 800 m (Ivanov et al., 1989; Egorov et al., 1998). At some of the shallow Crimean seeps, microbial mats were found associated with isotopically light carbonates. Aspects of the microbiology, sedimentology, mineralogy, and selected biomarker properties of these deposits were recently described (Pimenov et al., 1997; Michaelis et al., 2002; Treude et al., $2005,2007)$. Massive microbial mats cover up to 4-m-high carbonate buildups at methane seeps in anoxic waters of the 
northwestern Black Sea shelf. Strong

${ }^{13} \mathrm{C}$ depletions indicate incorporation of methane carbon into carbonates, bulk microbial biomass, and specific lipids. These buildups are formed by up to $10-\mathrm{cm}$-thick microbial mats that are internally stabilized by carbonate precipitates (Figure 7). Streams of gas bubbles emanate into the water column from holes in these structures. Apparently, the cavernous structure of these precipitates enables methane and sulfate to be transported and distributed throughout the massive mats. Smaller microbial structures and nodules from nearby areas were of the same morphology, with compact mats enclosing calcified parts and cavities (Figure 7). The development and structure of such reef systems is not yet understood and requires detailed ecosystem analysis based on habitat mapping and high-resolution sampling.

The second target of the HERMES "Microhab" expedition was the Sorokin Trough, which is characterized by diapiric structures formed in the context of compressional tectonics generated by the northward motion of the buried Tetyaev and Shatskii rises (Woodside et al., 1997). This tectonic activity causes fault movement and thus fluid migration to the seafloor. Abundant mud volcanoes and near-surface gas hydrate occurrences were identified in this area between 800- and 2000-m depths (Krastel et al., 2003), as well as active geochemical and microbiological processes associated with seepage (Stadnitskaia et al., 2005; Wallmann et al., 2007). The mud volcanoes have diameters of up to $2.5 \mathrm{~km}$ and heights of up to $120 \mathrm{~m}$ above the surrounding seafloor. Observations have focused on the flat-topped and very active Dvurechenskii mud volcano (DMV). Indicators for recent or present methane emission at DMV include the presence of gas hydrates in surface sediments, gas flares, highly gassy sediments, strong sulfidic smells from surface sediments, authigenic carbonate crusts, and the presence of microbial mats (Bohrmann et al., 2004).

In situ biogeochemical measurements along a transect from the mud volcano center to the outer rim (Figure 8) demonstrate clear zonation, from the highest upflow velocity and largest methane export at the active center located slightly north of the geographic center, to low flow and methane emission at the rim of the volcano. In a similar manner to other mud volcanoes, fluid flow is the main driver of the microbiological activity at DVM. As observed at the Håkon Mosby mud volcano, a high flow rate at the active center prevents sulfate derived from the bottom seawater from penetrating the sediment, thus limiting the anaerobic methane oxidation/sulfate reduction consumption of methane.

\section{CARBONATE CONSTRUCTIONS AT COLD SEEPS}

Various examples of authigenic carbonates from modern marine cold seeps have been described from continental margins worldwide (e.g., Campbell et al., 2002). They may or may not be associated with gas hydrates. After a decade of microbiological and geochemical studies, we know that in marine cold seep environments, methane and other hydrocarbon compounds contained in the ascending fluids are oxidized to $\mathrm{CO}_{2}$ by a microbial consortium of sulfate-reducing bacteria and methanotrophic archea (Boetius et al., 2000).

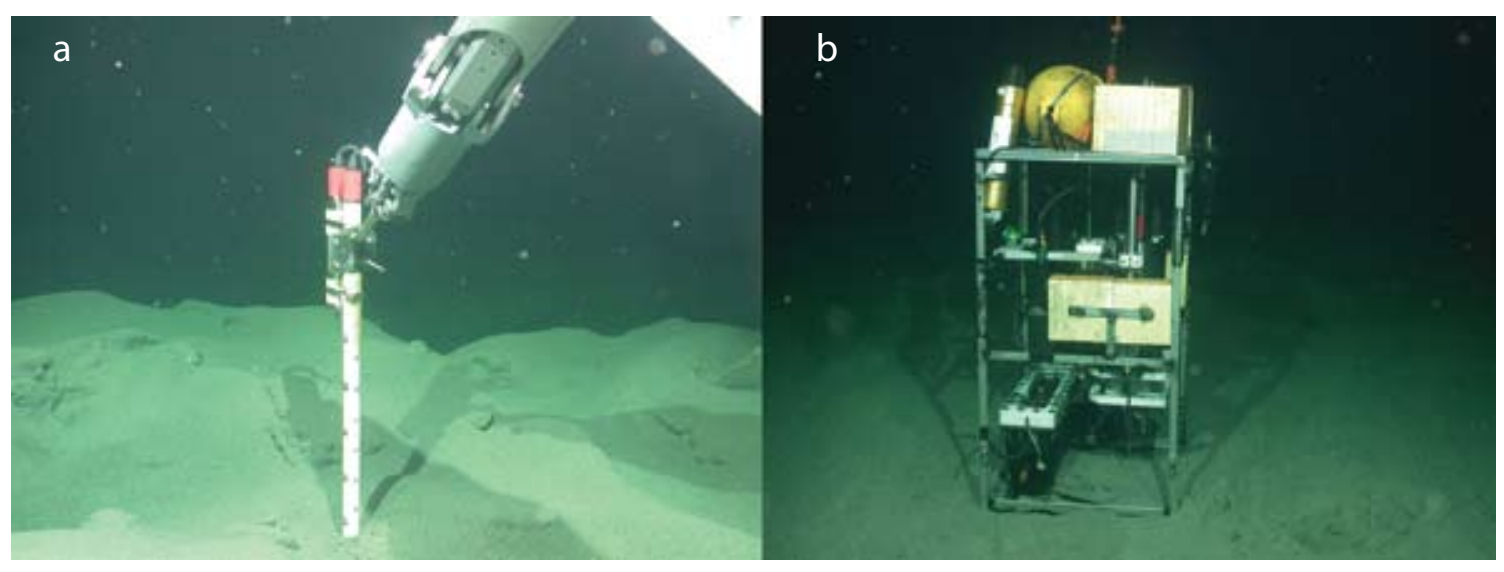

Figure 8. Images of deployments of in situ instruments at the Dvurechenskii mud volcano. (a) In situ temperature measurement. (b) In situ microprofiler measurement of sulfide, redox, and pH. Source: MARUM/MPI. M72/2 


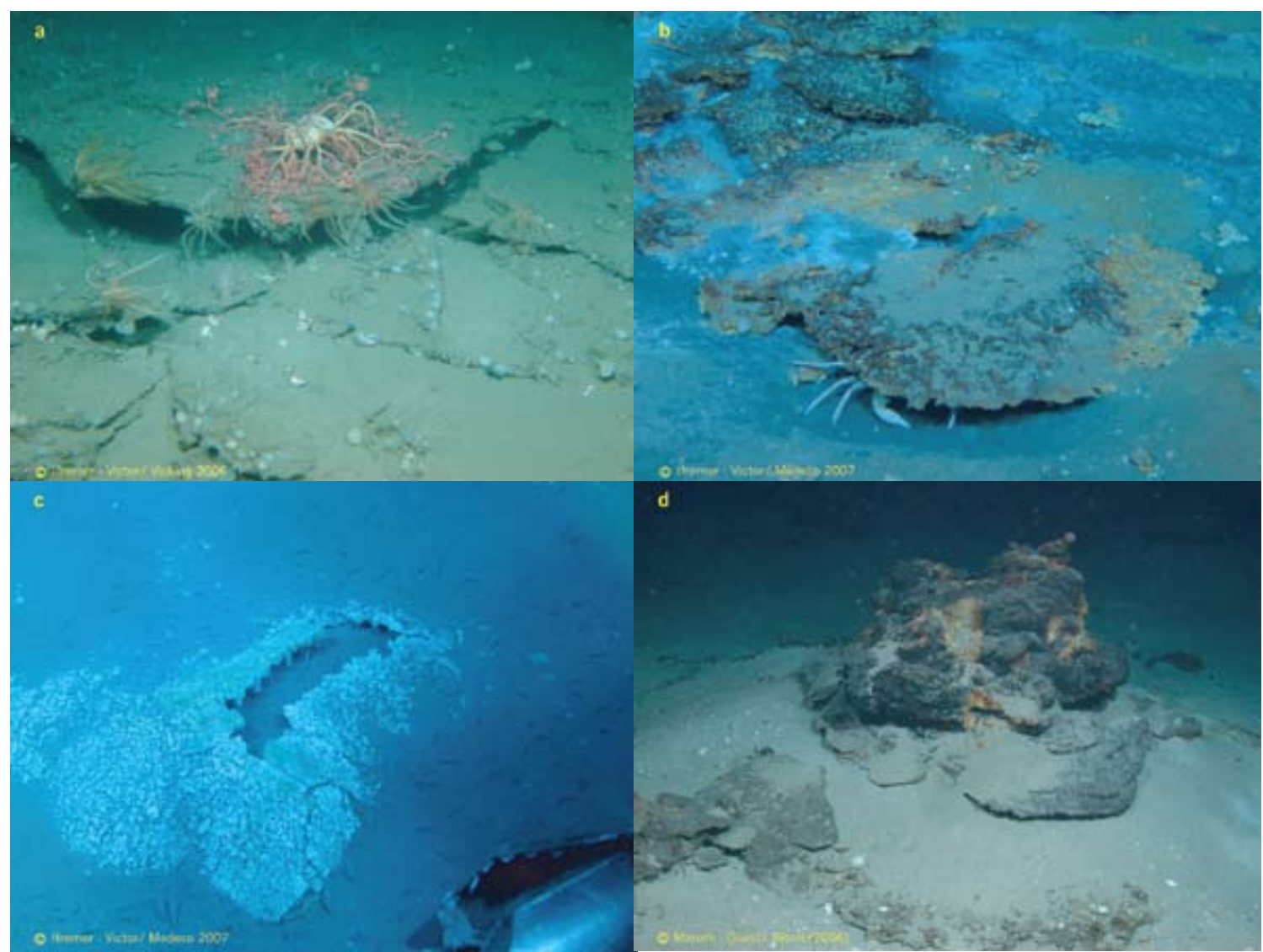

Figure 9. Various seafloor morphologies of cold seep authigenic carbonate constructions. (a) Fractured carbonate pavement colonized by megafauna on gas chimneys on the northeastern edge of the Storegga slide (Norwegian margin). (b) Porous slabs of carbonate crust surrounded by reduced black sediment covered with dead bivalve shells on the summit of Napoli mud volcano (Olimpi field, eastern Mediterranean). (c) Carbonate "soufflé" emerging from sediment covered with living polychaetes on the border of Cheops mud volcano (Menes caldera, Nile Deep Sea Fan, eastern Mediterranean). (d) Carbonate "tower" and carbonate slabs at the edge of Amon mud volcano (Nile Deep Sea Fan, eastern Mediterranean).

Anaerobic oxidation of methane is the main microbial process driving the precipitation of authigenic carbonate crusts and concretions within subsurface anoxic sediments. This process explains why the seafloor is often hardened by carbonate constructions at the sites of active methane seepage. The lateral and vertical extent of these authigenic carbonate constructions is controlled by the balance between the intensity of the venting fluid flux and the ability of microbial mats to oxidize methane and reduce sulfate. The microbial mat filter transforms the methane passing through the sediment and generates carbonate. However, the efficiency of this filter can be counteracted by high methane flux, so that methane can escape into the water column and may eventually reach the atmosphere. Numerical modeling of carbonate crust formation has shown that bioturbation and sedimentation rates are also important factors in controlling the flow of water and methane, and thus carbonate precipitation at cold seep sites (Luff et al., 2004).

The carbonate constructions observed at the seafloor exhibit various morphologies: massive to porous crusts centimeters to meters thick that form large pavements or fragmented slabs, circular chimneys, and irregular concretions corresponding to cemented bioturbation. These hard substrates are often colonized by fixed organisms such as tubeworms and molluscs (bivalves and gastropods), as well as by an abundant vagile fauna (crustaceans, fishes).

Authigenic carbonates provide records of the history of seep activity. Their mineralogy, and geochemical and isotopic signatures depend on the composition of the fluids and thus provide information on the origin of these fluids. 
It is noteworthy that carbonate mineral associations are generally dominated by aragonite and $\mathrm{Mg}$-calcite, although dolomite and ankerite may become the unique species as in the carbonate chimneys of the Gulf of Cádiz (Aloisi et al., 2000; Diaz-del-Rio et al., 2003; Gontharet et al., 2007). All cold-seep carbonates are characterized by very negative $\delta^{13} \mathrm{C}$ values, as low as $-54.7 \%$, clearly indicating that they are methanederived products. The lipid biomarkers entrapped in the carbonate network provide complementary information on the composition of the microbial communities that were involved during diagenetic processes, anaerobic oxidation of methane, sulfate reduction, and methanogenesis (Bouloubassi et al., 2006; Niemann et al., 2006b).

\section{HYDRATE AS A LONG-TERM}

\section{SOURCE OF METHANE FOR}

\section{CHEMOSYNTHETIC BIOTA AT}

\section{COLD SEEPS}

At seeps where methane is entering the water column as free gas, such as at the Håkon Mosby mud volcano (Sauter et al., 2006) and many localities in the Black Sea (Greinert et al., 2006), it is evident that there is an abundant supply of subseabed methane for chemosynthetic biota (Figure 10), but there are many seeps that support chemosynthetic biota where the methane is only in solution in the pore water that flows through the seep, such as those in the Nyegga region of the southeast Vøring plateau off Norway (Vanreusel et al., this issue). A question that arises is: how is a methane supply sufficient to support chemosynthetic biota at these seeps sustained without a supply of free methane gas from below? Methane hydrate beneath the seabed plays an important role where seeps lie within its stability field, generally in water depths greater than $400 \mathrm{~m}$. Hydrate provides a source of methane, and it buffers the concentration of methane in solution in pore water to that of the solubility of methane in the hydrate stability field (Figure 11).

Estimates of how long hydrate could provide a viable source of methane to chemosynthetic biota at the seabed under different conditions were made using a one-dimensional advectiondiffusion model based on the Nyegga area, where hydrate was cored at depths of less than $1 \mathrm{~m}$ beneath the seabed in the Sharic and Bobic pockmarks (Ivanov et al., 2007). The model assumes that,

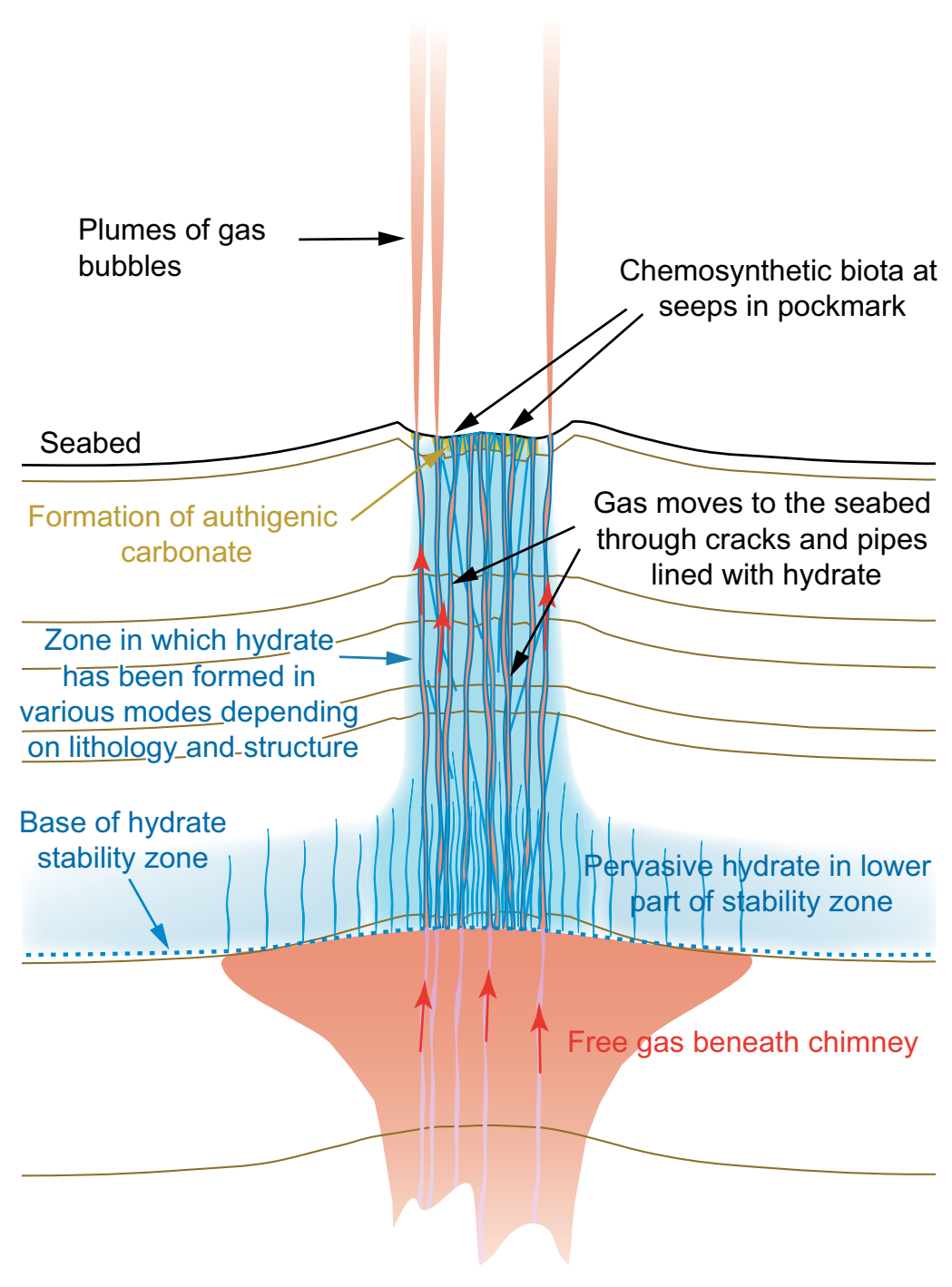

Figure 10. Illustration of a pockmark and underlying chimney during a phase of active expulsion of free gas. The passage of free gas through the hydrate stability zone is aided by the formation of hydrate around the pathways through which the gas is passing, inhibiting access of the gas to pore water and preventing conversion of all the gas to hydrate. Progressive formation of hydrate and carbonate near the seabed seals pathways, causing an outward migration of the active gas vents. 
initially, hydrate lies $1 \mathrm{~m}$ beneath the seabed and the sulfate-methane transition (SMT) is at $30-\mathrm{cm}$ depth. Above the SMT, methane is not present in the pore water, because it has been anaerobically oxidized with microbial mediation, taking the oxygen from sulfate that has diffused downward from the seawater to produce sulfide and bicarbonate (Boetius et al., 2000). If the SMT is much more than about 1-m deep, methane in pore water is out of reach of most of the biota living at or near the seabed.

Depletion of a layer containing $12.5 \%$ hydrate by chemical diffusion alone will cause the top to recede downward from 1-m to 3-m depth below the seabed after 1800 years (Figure 12). The SMT will deepen from 0.3 to $1 \mathrm{~m}$ and the methane flux will decrease from 2.1-0.7 $\mathrm{mol} \mathrm{m}^{-2} \mathrm{yr}^{-1}$. Consumption rates of methane by in situ chemosynthetic biota vary greatly and are species dependent (Torres et al., 2002; Boetius and Suess, 2004), but a rate of a few tenths of a mol m${ }^{-2} \mathrm{yr}^{-1}$ appears to be sufficient for some species (Niemann et al., 2006a). So, although the methane flux would still appear to be sufficiently high, the increasing depth of the SMT below $1 \mathrm{~m}$ would progressively reduce the viability of chemosynthetic biota.

Upward advection of methane in solution in pore water can halt the downward movement of the top of the hydrate and the SMT. For the model case, this is produced by a fluid flow rate of $35 \mathrm{~mm} \mathrm{yr}^{-1}$ with the concentration of methane buffered by the hydrate at $60 \mathrm{~mol} \mathrm{~m}^{-3}$. The concentration of methane in solution in the pore water that enters the layer containing hydrate and the rate of flow of the water control how quickly the hydrate is removed. The

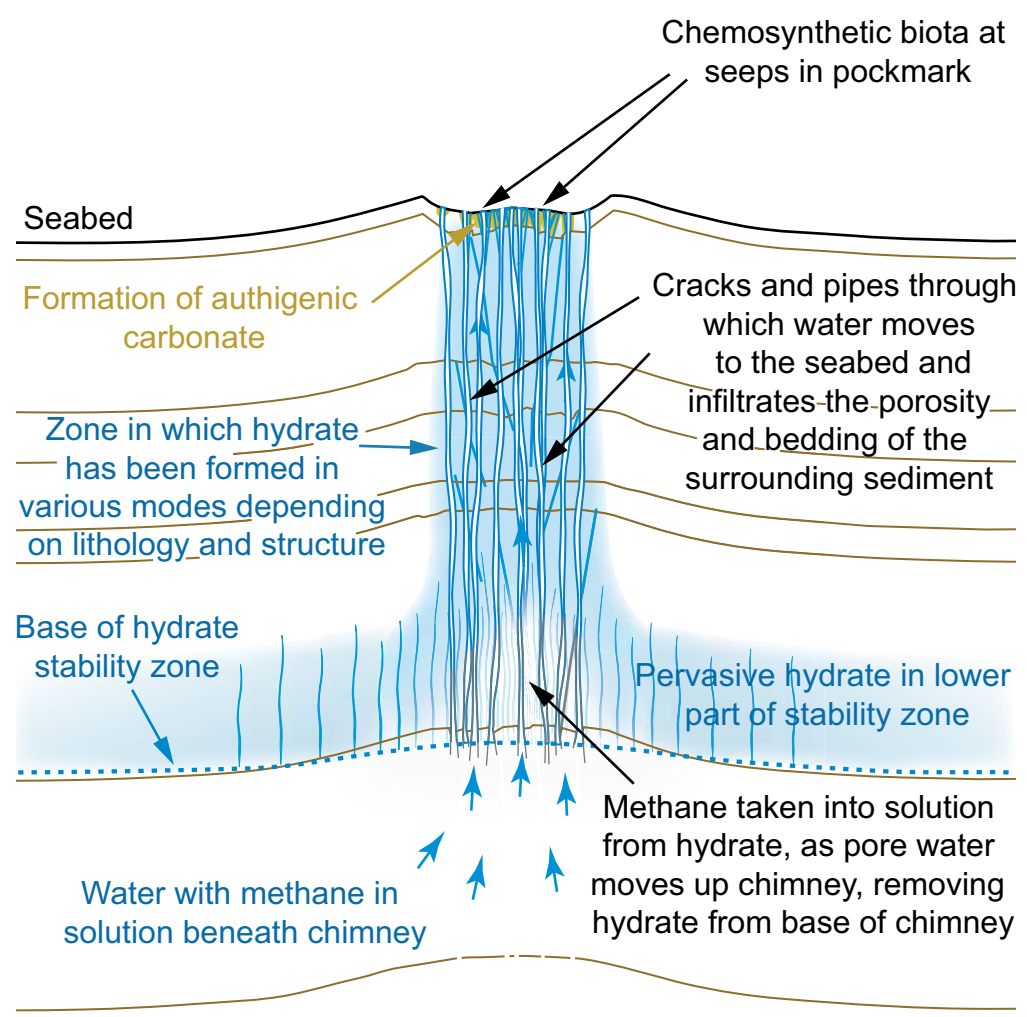

Figure 11. Illustration of a pockmark and underlying chimney when only pore water is migrating through the system. Methane from hydrate created during the free-gas expulsion phase keeps the methane in solution in the migrating pore water at saturation concentration, supporting chemosynthetic biota in the pockmark, until all the hydrate is removed in solution. This process may continue for thousands of years, with only moderate amounts of hydrate and concentration of methane in solution in the pore water entering the chimney from below.

layer would be diminished from beneath, where methane solubility is higher and the rising pore water first comes into contact with the hydrate (Figure 12). At one extreme, a 10-m-thick layer would be removed in 160 years if the concentration of methane in solution was zero and the fluid flow rate was $1 \mathrm{~m} \mathrm{yr}^{-1}$. In the case of the Nyegga pockmarks, however, where there is abundant evidence for the presence of free gas beneath the hydrate stability zone, it is probable that the concentration of methane in solution is near saturation, and so the rate of depletion of hydrate would be low. For a near-saturation methane concentration of $55 \mathrm{~mol} \mathrm{~m}^{-3}$ and a fluid flux of $35 \mathrm{~mm} \mathrm{yr}^{-1}$, it would take 5500 years to reduce the thickness of the hydrate by one meter, while providing a methane flux of $2.1 \mathrm{~mol} \mathrm{~m}^{-2} \mathrm{yr}^{-1}$ and maintaining the top of the hydrate and SMT at their initial depths.

In short, if hydrate had been produced at shallow depth by an event releasing a high volume of free gas in the past, an accumulation of methane hydrate of low-to-moderate concentration and a 


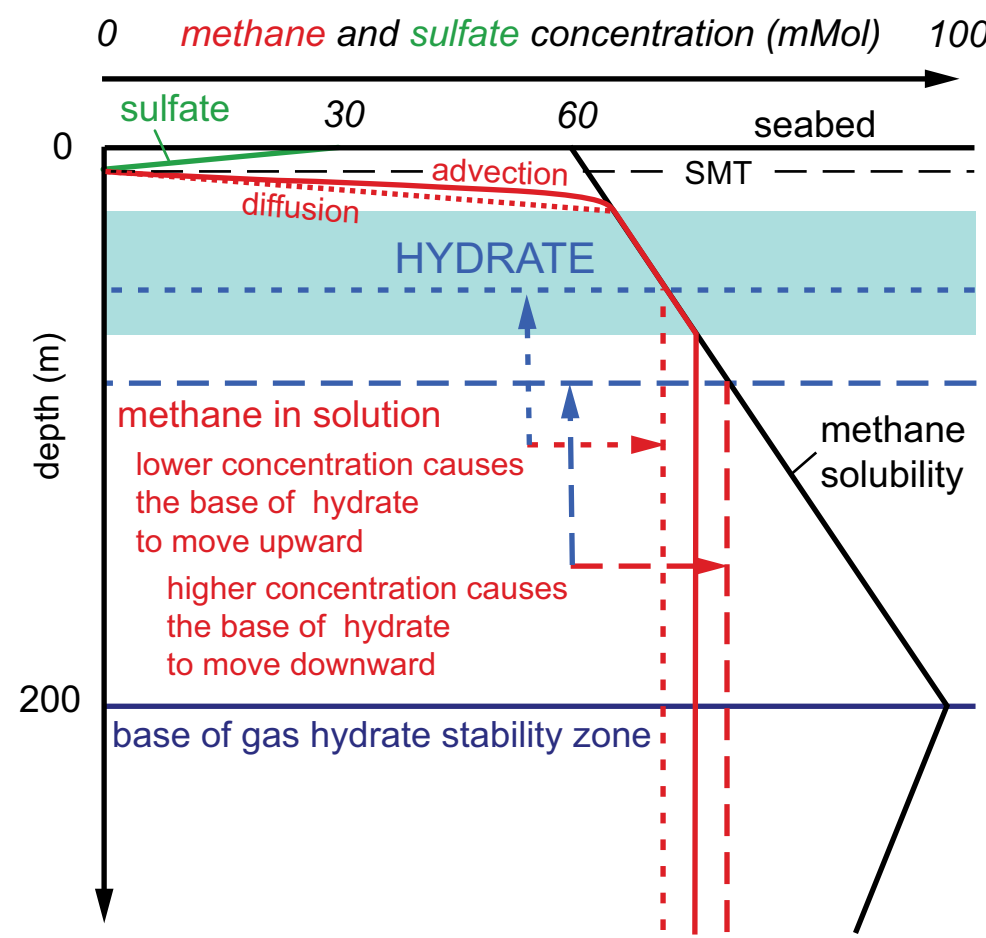

Figure 12. Schematic representation of the control of methane concentration beneath the seabed by the initial concentration of methane in solution in upwardly migrating pore water, the presence of hydrate, and sulfate in the seawater. The concentration of dissolved methane in the rising pore water controls the depth at which hydrate begins to form. If it is less than the lowest value of methane solubility, then all previously formed hydrate will be removed, but the rate of removal depends upon the degree to which the pore water is undersaturated and the rate of pore-water flow. few meters thick near the seabed could sustain communities of chemosynthetic biota for periods of several thousands to a few tens of thousands of years at seep sites where methane concentration in pore water is high but not exceeding saturation. Such an event may have lasted only a few years or less, depending on the efficiency with which hydrate was formed from the escaping free gas. Consequently, short-lived, catastrophic gas venting at the beginning of the Holocene or earlier could, without subsequent reactivation, have provided the source of methane for active, present-day communities of chemosynthetic biota.

\section{SUMMARY}

Natural hydrocarbon seeps are numerous in the European seas. A better knowledge of their distribution, nature, and drivers has been achieved through the HERMES project. Seepage is mainly related to the release of deep pressurized pore fluids. Overpressure is a result of rapid sedimentary loading or tectonic compression. Hydrocarbon gases dissolved in the pore fluid or at a concentration higher than saturation may be expelled as free gas. Selected study sites have shown variable vigor and distinct seepage. Expulsion of free methane bubbles occurs at Håkon Mosby mud volcano on the Nordic margin and at several highly active mud volcanoes on the Nile Deep Sea Fan. Spectacular emissions and accumulations of warm and hypersaline waters characterize mud volcanoes of the eastern Mediterranean Sea, which have formed above Messinian evaporites. Captain Arutyunov mud volcano in the Gulf of Cádiz illustrates an active seep characterized by slow advection of a methane-rich pore fluid.

Mud volcanoes have been important seep targets of the HERMES project, but other types of geological structures such as pockmarks, because of their dense distribution and large number in the European seas (e.g., the Nordic margin), may play an important role in the development of deep-sea biota at continental margins and should receive further attention. It is worth noting that highresolution swath mapping from surface vessels has proven to be an efficient exploratory method to identify potential fluid escape from geological structures on the seabed, where seepage activity was later confirmed by coring, lander, or ROV observations. These on-site observations were often combined with and guided by the acquisition of higherresolution bathymetric maps and acoustic images of the seabed. High-resolution mapping and in situ observations have emphasized the ecosystem zonation at individual seeps as a function of the intensity of the methane flux and active biogeochemical processes in response to this flux. Innovative in situ measurement tools have been used to estimate fluxes of water, hydrocarbons, and sulfide and to quantify biogeochemical processes (see Boetius and Wenzhöfer, this issue). A challenging issue that remains is determining the temporal 
variability of seepage activity. In the absence of free gas, methane hydrate in sediment beneath cold seeps may regulate the methane flux and sustain communities of chemosynthetic biota for periods of several thousand years at sites where hydrate formed during past gas release events.

\section{ACKNOWLEDGEMENTS}

We thank the crews and scientific parties of all HERMES-supported cruises, the results of which have contributed to produce this paper (OGS Explora 2005; FS Merian, 2005; RV Professor Logachev, TTR16-3 2006; FS Meteor M70/2 and M72/2, BIONIL 2006, and Microhab 2007; R/V Pourquoi pas?, Vicking 2006, MEDECO 2007). The HERMES Project is funded by the European Commission's Framework Six Programme, under the priority Sustainable Development, Global Change and Ecosystems, EC Contract No. GOCE-CT-2005-511234. Statoil provided financial support for the Professor Logachev TTR16 Leg 3 cruise. The University of Tromsø acknowledges the support by StatoilHydro Stavanger for three-dimensional seismic data (Figure 3a) to NFR project PETROMAKS Fluid Flow (169514/ S30). On the Calabrian Arc, data were acquired in collaboration with the HYDRAMED project at OGS, funded from 2004-2006 by a Marie Curie IntraEuropean Fellowship held by D. Praeg within the European Community Framework Six Programme (contract MEIF-CT-2003-501814). Figure 1 is a compilation that would not have been possible without the efficient assistance of J. Vitorino and C. Pata, Instituto Hidrografico, Lisbon; M. Alexandri and V. Lykousis, HCMR, Athens;
G. Lericolais and B. Loubrieu, Ifremer, Brest; and G. Buffet and L. Brosolo, G'éosciences Azur, Villefranche-surMer. We thank J.P. Mazé and N. Uchard, Ifremer, Brest, for their help in preparing the draft of this paper, and two reviewers for their comments. 四

\section{REFERENCES}

Aal, A.A., A. El Barkooky, M. Gerrits, H.J. Meyer, M. Schwander, and H. Zaki. 2001. Tectonic evolution of the eastern Mediterranean Basin and its significance for the hydrocarbon prospectivity of the Nile Delta deepwater area. GeoArabia (Manama) 6:363-384

Aloisi, G., C. Pierre, J.M. Rouchy, J.P. Foucher, J. Woodside, and the MEDINAUT Scientific Party. 2000. Methane-related authigenic carbonates of eastern Mediterranean Sea mud volcanoes and their possible relation to gas hydrate destabilisation. Earth and Planetary Science Letters 5675:1-18.

Bayon, G., L. Loncke, S. Dupré, J.-C. Caprais, E. Ducassou, S. Duperron, J. Etoubleau, J.P. Foucher, Y. Fouquet, S. Gontharet, and others. In Press. Multi-disciplinary investigation of fluid seepage on an unstable margin: The case of the Centre Nile deep sea fan. Marine Geology.

Bellaiche, G., L. Loncke, V. Gaullier, J. Mascle, T. Courp, A. Moreau, S. Radan, and O. Sardou. 2001. Le cône sous-marin du Nil et son réseau de chenaux profonds; Nouveaux résultats (campagne Fanil). Comptes Rendus de l'Académie des Sciences, Série II. Sciences de la Terre et des Planètes 333:399-404.

Boetius, A., K. Ravenschlag, C.J. Schubert, D. Rickert, F. Widdel, A. Giesecke, R. Amann, B.B. Jorgensen, U. Witte, and O. Pfannkuche. 2000. A marine microbial consortium apparently mediating anaerobic oxidation of methane. Nature 407:623-626.

Boetius, A., and E. Suess. 2004. Hydrate Ridge: A natural laboratory for the study of microbial life fueled by methane from near-surface gas hydrates. Chemical Geology 205:291-310.

Bohrmann, G., M. Ivanov, J.P. Foucher, V. Spiess, J. Bialas, J. Greinert, W. Weinrebe, F. Abegg, G. Aloisi, G. Artemov, and others. 2004. Mud volcanoes and gas hydrates in the Black Sea: New data from Dvurechenskii and Odessa mud volcanoes. Geo-Marine Letters 23:239-249.

Bouloubassi, I., G. Aloisi, R. Pancost, E. Hopmans, C. Pierre, and J.S. Sinninghe Damste. 2006. Archeal and bacterial lipids in authigenic carbonate crusts from eastern Mediterranean mud volcanoes. Organic Geochemistry 37:484-500.

Camera, L., A. Ribodetti, and J. Mascle. In press. Deep structures and seismic stratigraphy of the Egyptian continental margin from multi-channel seismic data. Bulletin of the Geological Society of London. Campbell, K.A., J.D. Farmer, and D. Des Marais. 2002. Ancient hydrocarbon seeps from the Mesozoic convergent margin of California: Carbonate geochemistry, fluids and palaeoenvironments. Geofluids 2:63-94.

Ceramicola, S., D. Praeg, and the OGS Explora Scientific Party. 2006. Mud volcanoes discovered on the Calabrian Arc: Preliminary results from the HERMES-HYDRAMED IONIO 2005 campaign. CIESM Workshop Monographs, 29:35-39.

Cita, M.B., and A. Camerlenghi, 1990. The Mediterranean Ridge as an accretionary prism in collisional context. Memorie della Societa Geologica Italiana 45:463-480.

Cita, M.B., W.B.F. Ryan, and L. Paggi. 1981. Prometheus mud breccia; An example of shale diapirism in the Western Mediterranean Ridge. Annales Geologiques des Pays Helleniques 30:543-570.

Coleman, D., and R. Ballard. 2001. A highly concentrated region of cold hydrocarbon seeps in the southeastern Mediterranean Sea. Geo-Marine Letters 21:162-167.

Crane, K., P.R. Vogt, E. Sundvor, A. Shor, and T. Reed IV. 1995. SeaMARC II investigations in the northern Norwegian-Greenland Sea. Meddelelser Norsk. Polarinstitutt 137:32-140.

De Beer, D., E. Sauter, H. Niemann, N. Kaul, J.P. Foucher, U. Witte, M. Schlûter, and A. Boetius. 2006. In situ fluxes and zonation of microbial activity in surface sediments of the Håkon Mosby mud volcano. Limnology and Oceanography 51:1,315-1,331.

Diaz-del-Rio, V., L. Somoza, J. Martinez-Frias, M.P. Mata, A. Delgado, F.J. Hernandez-Molina, R. Lunar, J.A. Martin-Rubi, A. Maestro, M.C. Fernandez-Puga, and others. 2003. Vast fields of hydrocarbon-derived carbonate chimneys related to the accretionary wedge/olistostrome of the Gulf of Cádiz. Marine Geology 195:177-200.

Dolson, J.C., P.J. Boucher, T. Dodd, and J. Ismail. 2002. Petroleum potential of an emerging giant gas province, Nile Delta and Mediterranean Sea off Egypt. Oil and Gas Journal 100:32-37.

Dolson, J.C., M.V. Shann, S. Matbouly, C. Harwood, R. Rashed, and H. Hammouda. 2001. The petroleum potential of Egypt. AAPG Memoir 74:453-482.

Dupré, S., J. Woodside, J.P. Foucher, G. de Lange, J. Mascle, A. Boetius, V. Mastalerz, A. Stadnitskaia, H. Ondréas, C. Huguen, and others. 2007. Seafloor geological studies above active gas chimneys off Egypt (Central Nile Deep Sea Fan). Deep Sea Research Part I 54:1,146-1,172.

Edy, C., H. Bisquay, and the shipboard scientific party. 2004. Microbathymetry on ROV 6000. Pp. 158-163 in The Expedition ARKTIS XIX/3 of the Research Vessel Polarstern in 2003. M. Klages, J. Thiede, and J.P. Foucher, eds, Ber. Polarforsch. Meeresforsch. 488 pp.

Egorov, V.N., U. Luth, C. Luth, and M.B. Gulin. 1998. Gas seeps in the submarine Dnieper Canyon, Black 
Sea: Acoustic, video and trawl data. Pp. 11-21 in Methane Gas Seep Explorations in the Black Sea (MEGASEEBS), Project Report. U. Luth, C. Luth, and H. Thiel, eds, Zentrum Für Meeres und Klimaforschung der Universität Hamburg, Hamburg, Germany.

Feseker, T., J.P. Foucher, and F. Harmegnies. 2008. Fluid flow or mud eruptions? Sediment temperature distributions on Håkon Mosby mud volcano, SW Barents Sea slope. Marine Geology 247:194-207.

Feseker, T., A. Dählmann, J.P. Foucher, and F. Harmegnies. In press. In-situ sediment temperature measurements and geochemical porewater data suggest highly dynamic fluid flow at Isis mud volcano, eastern Mediterranean sea. Marine Geology.

Forsberg, C., M. Hovland, S. Planke, A. Rike, J. Strout, G. Svano, H. Svensen, and T. Tjelta. 2005. Pockmarks with methane derived authigenic carbonate in the Norwegian Trench, Northern North Sea. 2005. Eos, Transactions, American Geophysical Union 86(52):A4.

Fusi, N., and N.H. Kenyon. 1996. Distribution of mud diapirism and other geological structures from long-range sidescan sonar (GLORIA) data in the Eastern Mediterranean Sea. Marine Geology 132:21-38.

Ginsburg, G., A.V. Milkov, V.A. Soloviev, A.V. Egorov, G.A. Cherkashev, P.R. Vogt, K. Crane, T.D. Laurenson, and M.D. Khutorskoy. 1999. Gas hydrate accumulation at the Håkon Mosby mud volcano. Geo-Marine Letters 19:57-67.

Gontharet, S., C. Pierre, M.M. Blanc-Valleron, J.M. Rouchy, Y. Fouquet, G. Bayon, J.P. Foucher, J. Woodside, J. Mascle, and the NAUTINIL Scientific Party. 2007. Nature and origin of diagenetic carbonate crusts and concretions from mud volcanoes and pockmarks of the Nile deep-sea fan (eastern Mediterranean Sea). Deep Sea Research Part II 54:1,292-1,311, doi:10.1016/j.dsr2.2007.04.007.

Greinert, J., Y. Artemov, V. Egorov, M. De Batist, and D. McGinnis. 2006. 1300-m-high rising bubbles from mud volcanoes at $2080 \mathrm{~m}$ in the Black Sea: Hydroacoustic characteristics and temporal variability. Earth and Planetary Science Letters 244:1-15

Hovland, M., H. Svensen, C.F. Forsberg, H. Johansen, C. Fichler, J.H. Fossa, R. Jonsson, and H. Rueslatten. 2005. Complex pockmarks with carbonate-ridges off mid-Norway: Products of sediment degassing. Marine Geology 218(1-4):191-206.

Hsu, K.J., M.B. Cita, and W.B.F. Ryan. 1973. The origin of the Mediterranean evaporites. Initial Reports of the Deep Sea Drilling Project 13(2):1,203-1,231.

Huguen, C., J.-P. Foucher, J. Mascle, H. Ondréas, M. Thouement, S. Gontharet, A. Stadnitskaia, C. Pierre, G. Bayon, L. Loncke, and others. In Press. Menes caldera, a highly active site of brine seepage in the Eastern Mediterranean Sea: "In situ" observations from the NAUTINIL expedition (2003).
Marine Geology.

Huguen, C., J. Mascle, E. Chaumillon, A. Kopf, J. Woodside, and T. Zitter. 2004. Structural setting and tectonic control of mud volcanoes from the Central Mediterranean Ridge (Eastern Mediterranean). Marine Geology 209:245-263.

Huguen, C., J. Mascle, J. Woodside, T. Zitter, and J.P. Foucher. 2005. Mud volcanoes and mud domes of the Central Mediterranean Ridge: Near-bottom and in situ observations. Deep Sea Research Part I 52:1,911-1,931.

Hustoft, S., J. Mienert, S. Bünz, and H. Nouzé. 2007. High-resolution 3D-seismic data indicate focussed fluid migration pathways above polygonal fault systems of the mid-Norwegian margin. Marine Geology 245:89-106.

Ivanov, M.K., A.I. Koniukhov, L.M. Kulnitskii, and A.A. Musatov. 1989. Mud volcanism in the deep Black Sea basin. Vestnik MGU, geologicheskaya seriya: $\mathrm{N} 3$.

Ivanov, M.K., A.F. Limonov, and T.C.E. van Weering. 1996. Comparative characteristics of the Black Sea and Mediterranean Ridge mud volcanoes. Marine Geology 132:253-271.

Ivanov, M., G.K. Westbrook, V. Blinova, E. Kozlova, A. Mazzini, H. Nouzé, and T.A. Minshull. 2007. First sampling of gas hydrate from the Voring Plateau. Eos, Transactions, American Geophysical Union 88:209-212.

Jerosch, K., M. Schlüter, J.P. Foucher, A.-G. Allais, M. Klages, and C. Edy. 2007. Spatial distribution of mud flows, chemoautotrophic communities, and biogeochemical habitats at Håkon Mosby Mud Volcano. Marine Geology 243:1-17.

Jørgensen, B.B., A. Weber, and J. Zopfi. 2001. Sulfate reduction and anaerobic methane oxidation in Black Sea sediments. Deep-Sea Research Part 1 48:2,097-2,120.

Judd, A., and M. Hovland. 2007. Seabed Fluid Flow. Cambridge University Press, 475 pp.

Krastel, S., V. Spiess, M. Ivanov, P. Shashkin, W. Weinrebe, and G. Bohrmann. 2003. Acoustic images of mud volcanoes in the Sorokin Trough, Black Sea. EGS-AGU-EUG Joint Assembly, Abstracts from the meeting held in Nice, France, 6-11 April 2003, Abstract \# 9069.

Kennicut, M.C., J.M. Brooks, R.R. Bidigare, R.R. Fay, T.L. Wade, and T.J. McDonald. 1985. Vent type taxa in a hydrocarbon seep region on the Louisiana Slope. Nature 317:351-353.

Kopf, A.J. 2002. Significance of mud volcanism. Reviews of Geophysics 40(2):1005, doi:10.1029/ 2000RG000093.

Loncke, L., J. Mascle, and Fanil Scientific Parties. 2004. Mud volcanoes, gas chimneys, pockmarks and mounds in the Nile deep-sea fan (eastern Mediterranean): Geophysical evidences. Marine and Petroleum Geology 21:669-689.

Lösekann, T., K. Knittel, T. Nadalig, B. Fuchs, H. Niemann, A. Boetius, and R. Amann. 2007. Diversity and abundance of aerobic and anaerobic methane oxidizers at the Haakon Mosby Mud
Volcano, Barents Sea. Applied and Environmental Microbiology 73(10):3,348-3,362.

Loubrieu, B., C. Satra, and R. Cagna. 2001. Cartography by multibeam echo-sounder of the Mediterranean Ridge and surrounding areas. Ifremer/CIESM. 1:1,500,000, two maps. CIESM Editions.

Luff, R., K. Wallmann, and G. Aloisi. 2004. Numerical modelling of carbonate crust formation at cold vent sites: Significance for fluid and methane budgets and chemosynthetic biological communities. Earth and Planetary Science Letters 221:337-353.

Lykousis, V., S. Alexandri, J. Woodside, G. de Lange, A. Dählmann, C. Perissoratis, K. Heeschen, C. Ioakim, D. Sakellariou, P. Nomikou, and others. In press. Mud volcanoes and gas hydrates in the Anaximander mountains (Eastern Mediterranean Sea). Marine and Petroleum Geology.

Mascle, J., L. Camera, N. Chamot-Rooke, C. Costis, V. Gaullier, L. Loncke, C. Nielsen, S. Operto, A. Ribodetti, F. Sage, and others. 2003. New constraints on the deep structure of the Eastern Mediterranean Sea from new MCS seismic reflection data. EGS-AGU-EUG Joint Assembly, Abstracts from the meeting held in Nice, France, 6-11 April 2003, Abstract \# 9172.

Mascle, J., T. Zitter, G. Bellaiche, L. Droz, V. Gaullier, L. Loncke, and Prismed Scientific Party. 2001. The Nile deep sea fan: Preliminary results from a swath bathymetry survey. Marine and Petroleum Geology 18:471-477.

Mazzini, A., H. Svensen, M. Hovland, and S. Planke. 2006. Comparison and implications from strikingly different authigenic carbonates in a Nyegga complex pockmark, G11, Norwegian Sea. Marine Geology 231:89-102.

MediMap Group, B. Loubrieu, and J. Mascle, 2005. Morpho-bathymetry of the Mediterranean Sea, CIESM/Ifremer special publication, Atlases and Maps, two maps at 1:2,000,000.

MediMap Group, B. Loubrieu, and J. Mascle, 2008. Morpho-bathymetry of the Mediterranean Sea, CIESM/Ifremer, 1:3,000,000.

Michaelis, W., R. Seifert, K. Nauhaus, T. Treude, V. Thiel, M. Blumenberg, K. Knittel, A. Gieseke, K. Peterknecht, T. Pape, and others. 2002. Microbial reefs in the Black Sea fueled by anaerobic oxidation of methane. Science 297:1,013-1,015.

Milkov, A., P.R. Vogt, G. Cherkashev, G. Ginsburg, N. Chernova, and A. Andriashev. 1999. Seafloor terrains of Håkon Mosby Mud Volcano as surveyed by deep-tow video and still photography. GeoMarine Letters 19:38-47.

Milkov, A., P.R. Vogt, K. Crane, A.Y. Lein, R. Sassen, and G.A. Cherkashev. 2004. Geological, geochemical, and microbial processes at the hydrate bearing Håkon Mosby mud volcano: A review. Chemical Geology 205:347-366.

Niemann, H., J. Duarte, C. Hensen, E. Omoregie, V.H. Magalhães, M. Elvert, L. Pinheiro, A. Kopf, and A. Boetius. 2006a. Microbial methane turnover at mud volcanoes of the Gulf of Cádiz. Geochimica et 
Cosmochimica Acta 70:5,336-5,355.

Niemann H., T. Lösekann, D. de Beer, M. Elvert, T. Nadalig, K. Knittel, R. Amann, E.J. Sauter, M. Schlüter, M. Klages, and others. 2006b. Novel microbial communities of the Haakon Mosby mud volcano and their role as methane sink. Nature 443:854-858.

Pimenov, V., I.I. Rusanov, M.N. Poglazova, L.L. Mityushina, D.Y. Sorokin, V.N. Khmelenina, and Y.A. Trotsenko. 1997. Bacterial mats on coral-like structures at methane seeps in the Black Sea. Microbiology 66:354-360.

Ryan, W.B.F. 1978. Messinian badlands on the southeastern margin of the Mediterranean Sea. Marine Geology 27:349-363.

Robertson, A.H.F., and the Ocean Drilling Program Leg 160 Shipboard Scientific Party. 1996. Mud volcanism on the Mediterranean Ridge: Initial results of Ocean Drilling Program Leg 160. Geology 24 (3):239-242.

Rossi, S., and R. Sartori.1981. A seismic reflection study of the external Calabrian Arc in the northern Ionian Sea (eastern Mediterranean). Marine Geophysical Researches 4:403-426.

Sartori, R. 2003. The Tyrrhenian back-arc basin and subduction of the Ionian lithosphere. Episodes 26(3):217-221.

Sage, L., and J. Letouzey. 1990. Convergence of the African and Eurasian Plate in the eastern Mediterranean. Pp. 49-68 in Petroleum and Tectonics in Mobile Belts. Proceedings of the $4^{\text {th }}$ IFP exploration and production research conference, Bordeaux, November 14-18, 1988. J. Letouzey, ed., Editions Technip, Paris.

Sauter, E.J., S.I. Muyakshin, J.L. Charlou, M. Schluter, A. Boetius, K. Jerosch, E. Damm, J.P. Foucher, and M. Klages. 2006. Methane discharge from a deepsea submarine mud volcano into the upper water column by gas hydrate-coated methane bubbles. Earth and Planetary Science Letters 243:354-365.

Sommer, S., M. Türk, S. Kriwanek, and O. Pfannkuche. 2008. Gas exchange system for extended in situ benthic chamber flux measurements under controlled oxygen conditions: First applicationSea bed methane emission measurements at Captain Arutyunov mud volcano. Limnology and Oceanography: Methods 6:23-33.

Sommer, S., P. Linke, O. Pfannkuche, T. Schleicher, V. Schneider, J. Deimling, A. Reitz, M. Haeckel, S. Flögel, and C. Hensen. In press. Seabed methane emissions and the habitat of frenulate tubeworms on the Captain Arutyunov mud volcano (Gulf of Cádiz). Marine Ecology Progress Series.

Stadnitskaia, A., G. Muyzer, B. Abbasa, M.J.L. Coolen, E.C. Hopmans, M. Baas, T.C.E. van Weeringa, M.K. Ivanov, E. Poludetkina, and J.E. Sinninghe Damste. 2005. Biomarker and 16S rDNA evidence for anaerobic oxidation of methane and related carbonate precipitation in deep-sea mud volcanoes of the Sorokin Trough, Black Sea. Marine Geology 217:67-96.

Stride, A.H., R.H. Belderson, and N.H. Kenyon.
1977. Evolving miogeanticlines of the East Mediterranean (Hellenic, Calabrian and Cyprus Outer Ridges). Philosophical Transactions of the Royal Society of London A284:255-285.

Torres, M.E., J. McManus, D. Hammond, M.A. de Angelis, K. Heeschen, S. Colbert, M.D. Tryon, K.M. Brown, and E. Suess. 2002. Fluid and chemical fluxes in and out of sediments hosting methane hydrate deposits on Hydrate Ridge, OR: I. Hydrological provinces. Earth and Planetary Science Letters. 201:525-540.

Treude, T., K. Knittel, M. Blumenber, R. Seifert, and A. Boetius. 2005. Subsurface microbial methanotrophic mats in the Black Sea. Applied and Environmental Microbiology 71:6,375-6,378.

Treude, T., V. Orphan, K. Knittel, A. Gieseke, and A. Boetius. 2007. Consumption of methane and $\mathrm{CO}_{2}$ by methanotrophic microbial mats from gas seeps of the anoxic Black Sea. Applied and Environmental Microbiology 73:2,271-2,283.

Wallmann, K., M. Drews, G. Aloisi, and G. Bohrmann. 2007. Methane discharge into the Black Sea and the global ocean via fluid flow through submarine mud volcanoes. Earth and Planetary Science Letters 248:544-559.

Woodside, J.M., M.K. Ivanov, and A.F. Limonov, eds. 1997. Neotectonics and fluid flow through seafloor sediments in the Eastern Mediterranean and Black Seas, Part II: Black Sea, IOC Technology Series 48, UNESCO, Paris, 128 pp.

Woodside, J.M., M.K. Ivanov, and A.F. Limonov. 1998. Shallow gas and gas hydrates in the Anaximander Mountains region, eastern Mediterranean Sea. Geological Society Special Publications 137:177-193.

Woodside, J.M., J. Mascle, T.A.C. Zitter, A.F. Limonov, M. Ergun, and A. Volkonskaia. 2002. The Florence Rise, the Western Bend of the Cyprus Arc. Marine Geology 185:177-194.

Zitter, T. 2004. Mud volcanism and fluid emissions in Eastern Mediterranean neotectonic zones. Ph.D. Dissertation. Vrije Universiteit, Amsterdam.

Zitter, T.A.C., C. Huguen, and J.M. Woodside. 2005. Geology of mud volcanoes in the eastern Mediterranean from combined sidescan sonar and submersible surveys. Deep Sea Research Part I 52:457-475. 